Article

\title{
Insecticidal Properties of Ocimum basilicum and Cymbopogon winterianus against Acanthoscelides obtectus, Insect Pest of the Common Bean (Phaseolus vulgaris, L.)
}

\author{
Álvaro Rodríguez-González ${ }^{1, *(1)}$, Samuel Álvarez-García ${ }^{1}$, Óscar González-López ${ }^{1}$, \\ Franceli Da Silva ${ }^{2}$ and Pedro A. Casquero ${ }^{1} \mathbb{D}$ \\ 1 Grupo Universitario de Investigación en Ingeniería y Agricultura Sostenible (GUIIAS), Instituto de Medio \\ Ambiente Recursos Naturales y Biodiversidad. Universidad de León, Avenida de Portugal 41, \\ 24071 León, Spain; salvg@unileon.es (S.Á.-G.); ogonl@unileon.es (Ó.G.-L.); pacasl@unileon.es (P.A.C.) \\ 2 Universidad Federal de Reconcavo de Bahia, Rui Barbosa 710, CEP 44380-000 Cruz das Almas, Brazil; \\ franceli@ufrb.edu.br \\ * Correspondence: alrog@unileon.es; Tel.: +34-987291000-5058
}

Received: 26 March 2019; Accepted: 21 May 2019; Published: 25 May 2019

\begin{abstract}
The bean weevil, Acanthoscelides obtectus Say (Coleoptera: Chrysomelidae: Bruchinae), causes severe post-harvest losses in the common bean, Phaseolus vulgaris L. The control of this insect is still poor and involves the use of conventional insecticides. There is an increasing demand in the search for new active substances and products for pest control towards reduction of adverse effects on human health and the environment. The protection of grains with alternative products, such as essential oils, is a possible alternative to meet the needs described above. Therefore, this investigation evaluated the applications of basil, Ocimum basilicum, and citronella, Cymbopogon winterianus, essential oils for A. obtectus control. These essential oils significantly reduced the bean weight losses and the number of beans damaged by A. obtectus at higher doses than 60 or $120 \mu \mathrm{L} /$ sample. The number of holes per bean did not differ between the doses of basil essential oil, not even at the dose of $60 \mu \mathrm{L}$, while it was higher at $120 \mu \mathrm{L}$, probably due to a lower capacity of movement of the insects treated with this dose and/or the oil's direct or indirect effects on the insects. Basil and citronella oils exhibited similar patterns of insecticidal activity over the insect, both directly in adult insects or indirectly over bean seeds. These essential oils affected the development of $A$. obtectus since the greatest doses applied on beans decreased the emergence of the bean weevil. The results prove the insecticidal capacity of the tested essential oils and hence their potential as active substances against $A$. obtectus in environmentally low risk pest control strategies. Supplementary trials should be conducted under real storage conditions.
\end{abstract}

Keywords: stored bean pest; essential oils; development; emergence; bean damage

\section{Introduction}

The bean weevil, Acanthoscelides obtectus Say (Coleoptera: Chrysomelidae: Bruchinae), is a pest that thrives primarily in stored common beans, Phaseolus vulgaris L. (wild and cultivated) [1-3]. A. obtectus attacks $P$. vulgaris seeds while they are still in the field, and the damage continues during storage, where it causes the greatest losses [4]. According to [5], when not treated, A. obtectus population grows exponentially causing the loss of whole crops within a few months.

The control and management of this pest in big storage facilities relies mainly on the use of phosphine, pyrethroids, organophosphates, and other synthetic insecticides [6], but these products 
are highly toxic to human health and the environment, to which is added the problem of being able to develop resistances on the part of the insects against these products [7]. Control applied by small farmers is virtually non-existent. As a result, research focuses on the development of new compounds with greater selectivity, less environmental persistence, and a variety of modes of action and new sustainable alternatives $[8,9]$.

Previous research has suggested that finding new compounds with greater selectivity, less environmental persistence, and a variety of modes of action is the key for a new generation of control strategies [9]. Plant metabolites and essential oils possess these characteristics and pose substantially fewer risks than those of traditional chemical insecticides. Therefore, natural plant products have been proposed worldwide as an alternative for the control of mites and insect pests [10-15], including A. obtectus $[16,17]$. Studies have shown the insecticidal potential of essential oils and their capacity to disrupt insect development $[18,19]$ through interference of the insect nervous system: andaminergic transmissions [20-23], GABAnergic transmissions [24-26], and the inhibition of acetylcholinesterases [27-29].

C. winterianus extracts have shown repellency and substantial control capacity against many species from different insect orders, such as Spodoptera exigua Hübner (Lepidoptera: Noctuidae) [30,31], Anopheles gambiae (Insecta: Culicidae) [32], and Callosobruchus maculatus Fabricius (Coleoptera: Chrysomelidae: Bruchinae) [33], the former being an important stored product pest. On the other hand, O. basilicum has confronted several storage pests, such as Sithopilus zeamais Motschulsky (Coleoptera: Curculionidae) [34] and Rhyzoperta dominica Fabricius (Coleoptera: Bostrichidae) [35], but does not show insecticidal activity against Coleoptera, a species belonging to other insect orders, such as S. exigua [31].

The present study explores the insecticidal potential of O. basilicum and C. winterianus essential oils against $A$. obtectus on stored beans by non-fumigant applications. Moreover, research on the biological activity of essential oils against the bean weevil during storage is extrapolated to the effects on the behavior of the adult insects and their development.

\section{Materials and Methods}

\subsection{Insects Rearing}

The original population of A. obtectus adults was collected during the year 2013 in different bean storage facilities, all of them located in the Protected Geographical Indication (PGI) "Alubia de La Bañeza-León," which certifies the quality and high standards of beans from this region (EC Reg. n.256/2010 published on 26 March 2010, OJEU L880/17). The insects were reared in glass jars (150 mm in diameter and $250 \mathrm{~mm}$ high) with common bean (Phaseolus vulgaris) seeds and covered with cloth, allowing gas exchange. Every three days all $A$. obtectus adults were removed from the jar in order to maintain a population of young adults ( 1 to 3 day old) ready to use in the experiments. A. obtectus adults, before and after the treatments, were kept in a chamber with a controlled temperature $\left(24 \pm 1{ }^{\circ} \mathrm{C}\right)$, humidity $(60 \pm 5 \%)$, and a photoperiod of $16 \mathrm{~h}$ of light (luminous intensity of $1000 \mathrm{lux}$ ) and $8 \mathrm{~h}$ of darkness.

\subsection{Essential Oils}

O. basilicum and C. winterianus Java type essential oils obtained by hydrodestillation were purchased from Naissance (Neath, Wales). Volatile components of essential oils were identified by gas chromatography (GC) according to the information provided by the company described above. Analysis for the main compounds are depicted in Table 1. 
Table 1. Composition of basil and citronella essentials oils obtained with gas chromatographic analysis.

\begin{tabular}{ccc}
\hline Essential Oil & Compounds (\%) & Total (\%) \\
\hline & Citral (0.70) & \\
& Citronellol (11.50) & 71.70 \\
O. basilicum & Citronellal (34.00) & \\
& Geraniol (22.00) & \\
& Limonene (3.50) & \multirow{2}{*}{91.80} \\
\hline \multirow{2}{*}{ C. winterianus } & Estragol (74.00) & \\
\hline
\end{tabular}

\subsection{Design of Experiments}

\subsubsection{Experiment 1: Essential Oil Effects on A. obtectus Adults}

This bioassay was conducted to determine the dose-dependent toxicity of $O$. basilicum and $C$ winterianus essential oils against $A$. obtectus adults. For the treatments application, a Potter Tower (Burkard Scientific Limited, Uxbridge, UK) [36] of manual loading coupled to an air compressor was used. The total volume used in each spray was $1 \mathrm{~mL}$, applied on Petri dishes (90 $\mathrm{mm}$ in diameter) covered with a sterile filter paper (Sigma-Aldrich Chemie $\mathrm{GmbH}$, Steinheim, Germany), to make sure that the treatments were retained, at $40 \mathrm{kPa}$. Five doses $(6,12,24,60$, and $120 \mu \mathrm{L} /$ petri dish) of $O$. basilicum and C. winterianus were diluted in ethanol, and four replicates were performed for each of them. A treatment with ethanol (without oil) was used as a control. After application of treatments, twenty unsexed 1 to 3 day old A. obtectus were placed in the Petri dish. From now, 'Petri dish' will be considered as the basic test unit. The Petri dishes were kept in a chamber with a controlled temperature $\left(24 \pm 1{ }^{\circ} \mathrm{C}\right)$, humidity $(60 \pm 5 \%)$, and a photoperiod of $16 \mathrm{~h}$ of light (luminous intensity of 1000 lux) and $8 \mathrm{~h}$ of darkness. On the covers of Petri dishes, 8 holes of $1 \mathrm{~mm}$ diameter $\left(8 \mathrm{~mm}^{2}\right)$ were made to avoid the vapor accumulation effect from the treatments. Daily monitoring was carried out during the following 15 days after the application of each dose of essential oil, counting the mortality of A. obtectus adults.

\subsubsection{Experiment 2: Essential Oil Effects on the Development of A. obtectus}

The second bioassay was conducted to determine the toxicity (sublethal effects) of the essential oils against $A$. obtectus adults when sprayed over $P$. vulgaris seeds. The same doses of each essential oil as described above were used. The treatments were applied with a Potter Tower (Burkard Scientific Limited, Uxbridge, UK) [36] over $70 \mathrm{~g}$ of bean seeds that were placed in $0.33 \mathrm{~L}$ glass jars ( $80 \mathrm{~mm}$ in diameter and $85 \mathrm{~mm}$ in height). After the application, the jars were manually shaken for $60 \mathrm{~s}$, ensuring a complete distribution of the essential oil over the beans. After the treatment's application, twenty unsexed 1 to 3 day old $A$. obtectus adults were placed in each jar, and the jars were kept under controlled conditions of temperature $\left(24 \pm 1{ }^{\circ} \mathrm{C}\right)$, humidity $(60 \pm 5 \%)$, and a photoperiod of $16 \mathrm{~h}$ of light (luminous intensity of $1000 \mathrm{lux}$ ) and $8 \mathrm{~h}$ of darkness. On the covers of the glass jars, 8 holes of $1 \mathrm{~mm}$ diameter $\left(8 \mathrm{~mm}^{2}\right)$ were made to avoid the vapor accumulation effect from the treatments. Daily monitoring was carried out during the following 15 days after the application of each treatment, counting the mortality of $A$. obtectus adults. Five doses $(18,36,72,180$ and $360 \mu \mathrm{L} /$ litre) of $O$. basilicum and $C$. winterianus were diluted in ethanol. A treatment with ethanol was used as a control. Four replicates were used for each dose, and the doses were calculated as $\mu \mathrm{L}$ of essential oil/volume of the container. From day 32 after the treatment application on the beans, the number of A. obtectus that emerged from the beans (first generation) was recorded. Likewise, from day 48 , the number of damaged beans (with at least one hole), holes per bean, and the weight loss of the damaged beans were also recorded in this experiment. 


\subsection{Statistical Analysis}

Experiment 1. A randomly completed experiment Generalized Linear Model (GLM) procedure, with five doses for each essential oil and four replicates, was subjected to ANOVA (data means were normally distributed and presented homocedasticity). Differences $(p<0.05)$ on the same day among doses (within the same essential oil), and the control, were examined by mean comparisons using the Least Significant Difference (LSD) test. The mortality data were corrected with the Abbott's formula [37] in the experiment described. Mean values and standard errors are given in Figure 1 (Mortality of A. obtectus on Petri dishes).

Experiment 2. A randomly completed experiment Generalized Linear Model (GLM) procedure, with five doses for each essential oil and four replicates, was subjected to ANOVA (data means were normally distributed and presented homocedasticity). Differences $(p<0.05)$ among insecticidal activity on beans, accumulated emergence, bean weight loss, number of damaged beans, and number of holes by beans among the doses (within the same essential oils), and the control, were examined by mean comparisons using the Least Significant Difference (LSD) test. Mean values and standard errors are given in Figure 2 (insecticidal activity on beans), Figure 4 (bean weight loss) and Table 2 (number of damaged beans and number of holes by bean).

\section{Results}

\subsection{Mortality of A. obtectus Adults against Different Doses of Essential Oils (Experiment 1)}

Figure $1 \mathrm{~A}, \mathrm{~B}$ show significant differences among doses of essentials oils when they were applied directly on A. obtectus adults placed in Petri dishes.

For O. basilicum essential oil, the best control was achieved for the dose $120 \mu \mathrm{L}$ on day 15 after application, killing $74.94 \pm 3.19 \%$ of the adults evaluated. This value was significantly greater $(\mathrm{F}=25.31$; $\mathrm{df}=5.18 ; p<0.0001)$ than the obtained for the other doses tested, except when applying $60 \mu \mathrm{L}$ of essential oil $(70.08 \pm 5.17 \%$ of mortality). The doses of 24 and $12 \mu \mathrm{L}$ were able to kill around $62 \%$ of adults on day 15th, not significantly greater than the mortality obtained by the $6 \mu \mathrm{L}$ dose, which was $58.02 \pm 4.58 \%$ on day 15 th. The control treatment significantly differed from the 1 st day after application, in which percentage of mortality was $16.25 \pm 2.93 \%$ on day 15 th (Figure $1 \mathrm{~A}$ ).

Likewise, the best control capacity obtained for $C$. winterianus essential oil was achieved for the dose $120 \mu \mathrm{L}$ on day 15 after application, killing $70.25 \pm 4.58 \%$ of the adults evaluated. This value was significantly greater $(\mathrm{F}=15.73 ; \mathrm{df}=5.18 ; p<0.0001)$ than for the other doses. The doses 60 and $24 \mu \mathrm{L}$ were able to kill $59.50 \pm 2.46$ and $57.75 \pm 5.39 \%$ of adults respectively, significantly higher than the mortality obtained for the $12 \mu \mathrm{L}$ and $6 \mu \mathrm{L}$ doses $(43.28 \pm 3.19$ and $42.68 \pm 4.10 \%$ of adults died with these doses on day 15th). Control treatment differed significantly from the 5th day after application, in which percentage of mortality was $14.25 \pm 2.39 \%$ on day 15 th (Figure $1 \mathrm{~B}$ ). 

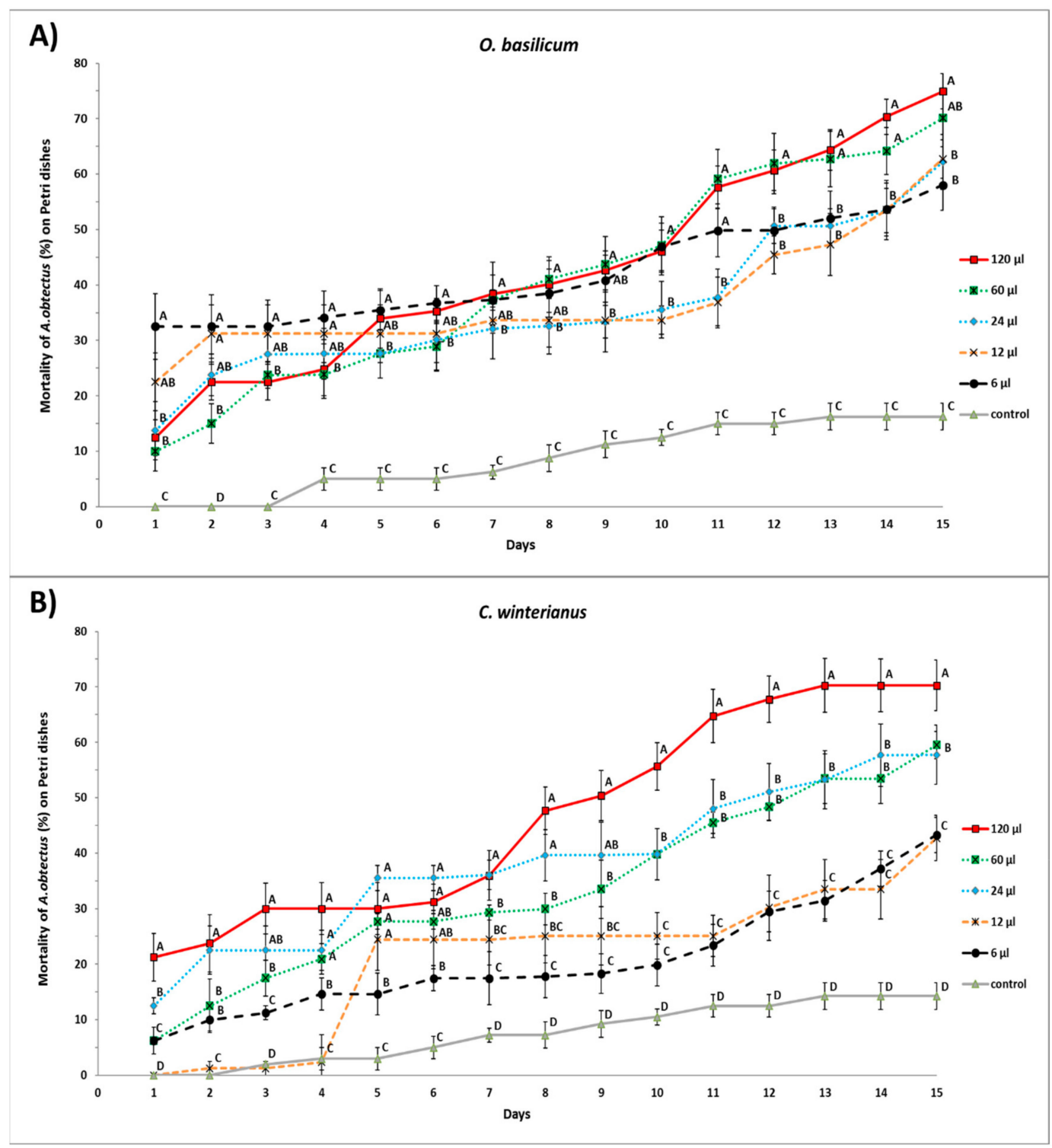

Figure 1. Accumulated mortality of A. obtectus on Petri dishes exposed to different doses of O. basilicum (A) and C. winterianus (B) essential oils. Different capital letters indicate significant differences among doses and control for the same day; least significant difference (LSD) test at 0.05 . The symbols represent the mean of four replicates for each dose. Vertical bars represent the Standard Error (SE) of the mean.

\subsection{Effect of Essential Oils on the Development of A. obtectus (Experiment 2)}

\subsubsection{Persistence of Insecticidal Activity on Beans}

Significant differences were observed during the first days of the evaluation over the insect mortality when beans were treated with different doses of $O$. basilicum and $C$. winterianus essential oils.

On the 6th day of the evaluation for the test carried out using O. basilicum, the $120 \mu \mathrm{L}$ dose was able to kill $24.43 \pm 4.06 \%$ of the initial insect population, significantly greater $(\mathrm{F}=2.78 ; \mathrm{df}=5.18 ; p=0.049)$ than the mortality obtained by rest of doses evaluated. Meanwhile, on the 8th day, the $60 \mu \mathrm{L}$ and $120 \mu \mathrm{L}$ doses were able to kill more than $50 \%$ of the adult insects, being significantly higher $(\mathrm{F}=9.04$; $\mathrm{df}=5.18 ; p<0.0001)$ than the control achieved by 24,12 , and $6 \mu \mathrm{L}$ doses.

Finally, the $120 \mu \mathrm{L}$ dose caused a total control (100\% of insects died) from the 11 th day of evaluation, whereas beans treated with 60 and $24 \mu \mathrm{L}$ doses achieved the total control of the insects only from day 
13th. From the 7th day onwards, mortality achieved by all doses was significantly higher than the control treatment, in which percentage mortality was $22.50 \pm 1.44 \%$ on day 15 th (Figure $2 \mathrm{~A}$ ).

As regards C. winterianus essential oil, on the 8th day of evaluation, the $120 \mu \mathrm{L}$ dose was able to kill $48.66 \pm 4.41 \%$ of the evaluated insect population, only significantly greater $(\mathrm{F}=7.48 ; \mathrm{df}=5.18$; $p<0.0001$ ) than the obtained by $60 \mu \mathrm{L}$ dose. Nevertheless, on day 9, a $120 \mu \mathrm{L}$ dose was able to kill more than $72 \%$ of the insects, being significantly greater $(\mathrm{F}=20.09$; $\mathrm{df}=5.18 ; p<0.0001)$ than the obtained by other doses evaluated, with the exception of $12 \mu \mathrm{L}(64.18 \pm 5.59 \%)$. Finally, when using a $120 \mu \mathrm{L}$ dose, a total control (100\% of insects died) was achieved from day 11th. Doses of 24 and $6 \mu \mathrm{L}$, were able to kill $100 \%$ of the insects only from day 13 . Again, mortality observed for all doses was significantly higher than the control treatment from the 7th day onwards, in which the percentage mortality was $21.60 \pm 1.93 \%$ on day 15 th (Figure $2 B$ ).

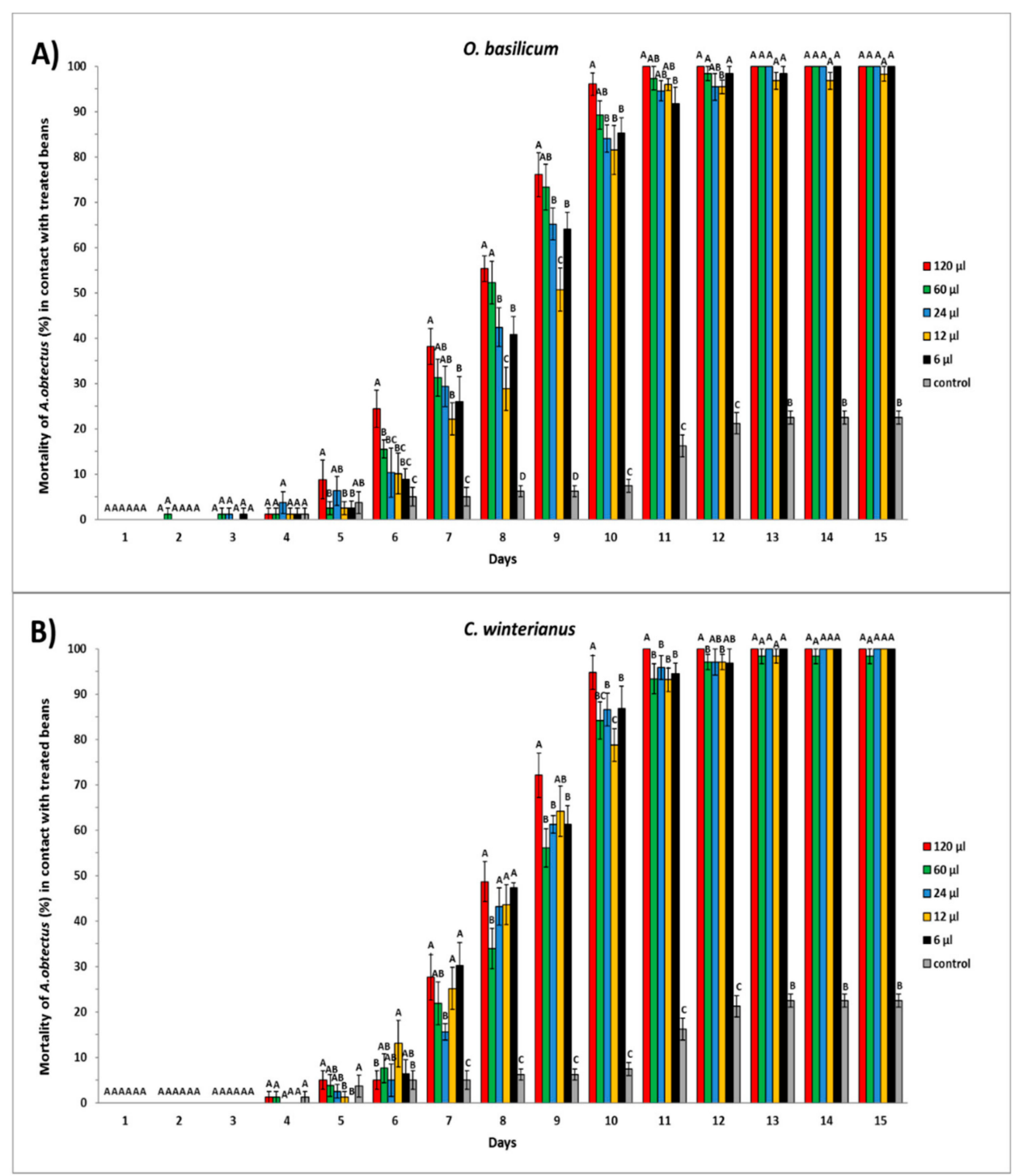

Figure 2. Mortality of A. obtectus in $0.33 \mathrm{~L} /$ glass jars exposed to beans treated with different doses of O. basilicum (A) and C. winterianus (B) essential oils. Different capital letters indicate significant differences among doses and control for the same day; LSD test at 0.05 . The symbols represent the mean of four replicates for each dose. Vertical bars represent the Standard Error (SE) of the mean. 
3.2.2. Accumulated Emergence of A. obtectus Adults from Beans Treated with Different Doses of Essential Oils

Different doses of $O$. basilicum and C. winterianus essential oils applied over beans affected the bean weevil emergence. The emergence period began 32 days after the application of the oils, and concluded 16 days later, on day 48.

The total emergence of bean weevil adults from beans treated with any of O. basilicum doses on the 37 th day of evaluation was significantly lower $(\mathrm{F}=2.98$; $\mathrm{df}=5.18 ; p=0.039)$ than in the control treatment $(110.25 \pm 5.14)$. In the last day of emergence (day 48), the treatment of beans with $120 \mu \mathrm{L}$ and $60 \mu \mathrm{L}$ reduced significantly $(\mathrm{F}=3.00 ; \mathrm{df}=5.18 ; p=0.045)$ the number of insects that emerged $(61.25 \pm 4.31$ and $66.75 \pm 4.96$, respectively) compared to the treatment $12 \mu \mathrm{L}, 6 \mu \mathrm{L}$ doses and the control (Figure 3A).

The insect emergence from beans treated with any of the $C$. winterianus doses applied was significantly lower $(\mathrm{F}=7.12 ; \mathrm{df}=5.18 ; p=0.018)$ than the results obtained in the control treatment $(110.25 \pm 4.55)$ on the 37 th day of evaluation. In the last day of emergence (day 48$)$, the treatment of beans with $120 \mu \mathrm{L}$ dose significantly reduced $(\mathrm{F}=4.27 ; \mathrm{df}=5.18 ; p=0.026)$ the number of insects that emerged $(53.50 \pm 3.40)$ compared to the rest of doses $(60,24,12,6 \mu \mathrm{L})$ and the control (Figure 3B).

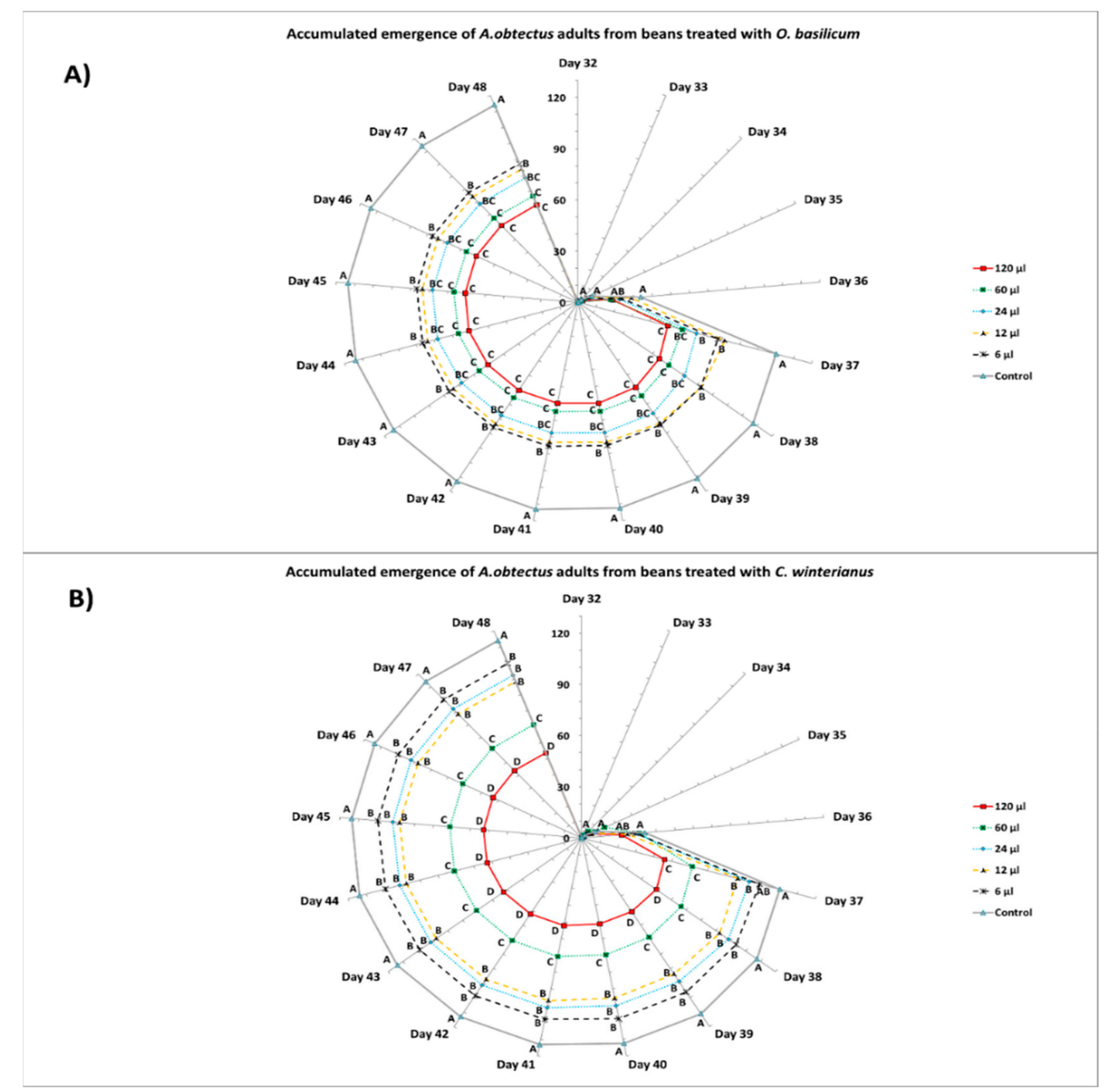

Figure 3. Accumulated emergence (mean $\pm \mathrm{SE}$ ) of $A$. obtectus adults in $0.33 \mathrm{~L} /$ glass jar from beans treated with different doses of O. basilicum (A) and C. winterianus (B) essential oils. Different capital letters indicate significant differences among doses and control for the same day; LSD test at 0.05. 


\subsubsection{Bean Damage}

Applications of different doses of O. basilicum and C. winterianus over beans repelled A. obtectus attack, significantly reducing the number of beans affected (beans damaged) by the insects after treatment with $O$. basilicum $(\mathrm{F}=13.29 ; \mathrm{df}=5.18 ; p<0.0001)$ and $C$. winterianus $(\mathrm{F}=5.93 ; \mathrm{df}=5.18$; $p=0.002$ ) essential oils (Table 1 ).

The number of holes per bean was significantly higher for the beans treated with $120 \mu \mathrm{L}$ of the basil essential oil $(\mathrm{F}=2.60 ; \mathrm{df}=5.18 ; p=0.048)$ compared to those treated with the lower doses (except the $60 \mu \mathrm{L}$ dose) and the control. There were no significant differences in the number of holes per bean after the application of the different doses of C. winterianus and the control treatment (Table 2).

Table 2. Number of damaged beans (mean \pm SE) and number of holes per bean (mean \pm SE) caused by A. obtectus adults that emerged from $70 \mathrm{~g}$ of beans treated in $0.33 \mathrm{~L} /$ glass jars with different doses of O. basilicum and C. winterianus essential oils.

\begin{tabular}{llll}
\hline Essential Oil & $\begin{array}{l}\text { Dose } \\
(\mu \mathbf{L})\end{array}$ & $\begin{array}{l}\text { Number of Beans Damaged } \\
\text { (with at Least One Hole) }\end{array}$ & Number of Holes Per Bean \\
\hline & Control & $51.50 \pm 4.99 \mathrm{a}^{1}$ & $2.09 \pm 0.67 \mathrm{~b}^{1}$ \\
& 6 & $36.75 \pm 3.81 \mathrm{~b}$ & $2.40 \pm 0.18 \mathrm{~b}$ \\
O. basilicum & 12 & $36.00 \pm 3.39 \mathrm{~b}$ & $2.36 \pm 0.35 \mathrm{~b}$ \\
& 24 & $25.00 \pm 4.63 \mathrm{c}$ & $2.82 \pm 0.63 \mathrm{~b}$ \\
& 60 & $23.25 \pm 2.13 \mathrm{~cd}$ & $2.98 \pm 0.46 \mathrm{ab}$ \\
& 120 & $13.50 \pm 1.55 \mathrm{~d}$ & $4.90 \pm 1.21 \mathrm{a}$ \\
\hline $\mathrm{F}$ & 13.299 & 2.304 \\
& $\mathrm{df}$ & 5.18 & 5.18 \\
& $\mathrm{P}$ & $\leq 0.000$ & 0.088 \\
\hline Control & $51.50 \pm 4.99 \mathrm{a}{ }^{1}$ & $2.09 \pm 0.67 \mathrm{a}{ }^{1}$ \\
& 6 & $51.00 \pm 3.39 \mathrm{a}$ & $2.15 \pm 0.08 \mathrm{a}$ \\
& 12 & $45.25 \pm 3.92 \mathrm{ab}$ & $2.33 \pm 0.11 \mathrm{a}$ \\
& 24 & $41.00 \pm 3.85 \mathrm{ab}$ & $2.23 \pm 0.35 \mathrm{a}$ \\
& 60 & $36.50 \pm 3.66 \mathrm{bc}$ & $1.92 \pm 0.27 \mathrm{a}$ \\
& 120 & $23.75 \pm 5.48 \mathrm{c}$ & $2.09 \pm 0.26 \mathrm{a}$ \\
\hline $\mathrm{F}$ & 5.935 & 0.154 \\
$\mathrm{df}$ & 5.18 & 5.18 \\
\hline
\end{tabular}

\footnotetext{
${ }^{1}$ Different lowercase letters indicate significant differences among beans treated by different doses of essential oils
} and control; LSD test at 0.05 .

\subsubsection{Bean Weight Losses}

Beans incubated with $A$. obtectus, which were previously treated with different doses of O. basilicum, showed weight losses ranging between $0.81 \pm 0.21 \%(120 \mu \mathrm{L}$ dose $)$ and $2.29 \pm 0.31 \%(6 \mu \mathrm{L}$ dose $)$, while beans under a control treatment $(2.44 \pm 0.64 \%)$ had a weight loss significantly higher $(\mathrm{F}=2.99 ; \mathrm{df}=5.18$; $p=0.039$ ) than the rest of the doses evaluated (Figure 4).

Finally, beans incubated with $A$. obtectus, which were previously treated with different doses of C. winterianus, showed weight losses ranging between $0.83 \pm 0.31 \%(120 \mu \mathrm{L}$ dose $)$ and $2.01 \pm 0.38 \%$ $(6 \mu \mathrm{L}$ dose), while beans under the control treatment $(2.44 \pm 0.64 \%)$ had weight loss significantly higher $(\mathrm{F}=2.77 ; \mathrm{df}=5.18 ; p=0.050)$ than the rest of doses evaluated (Figure 4$)$. 


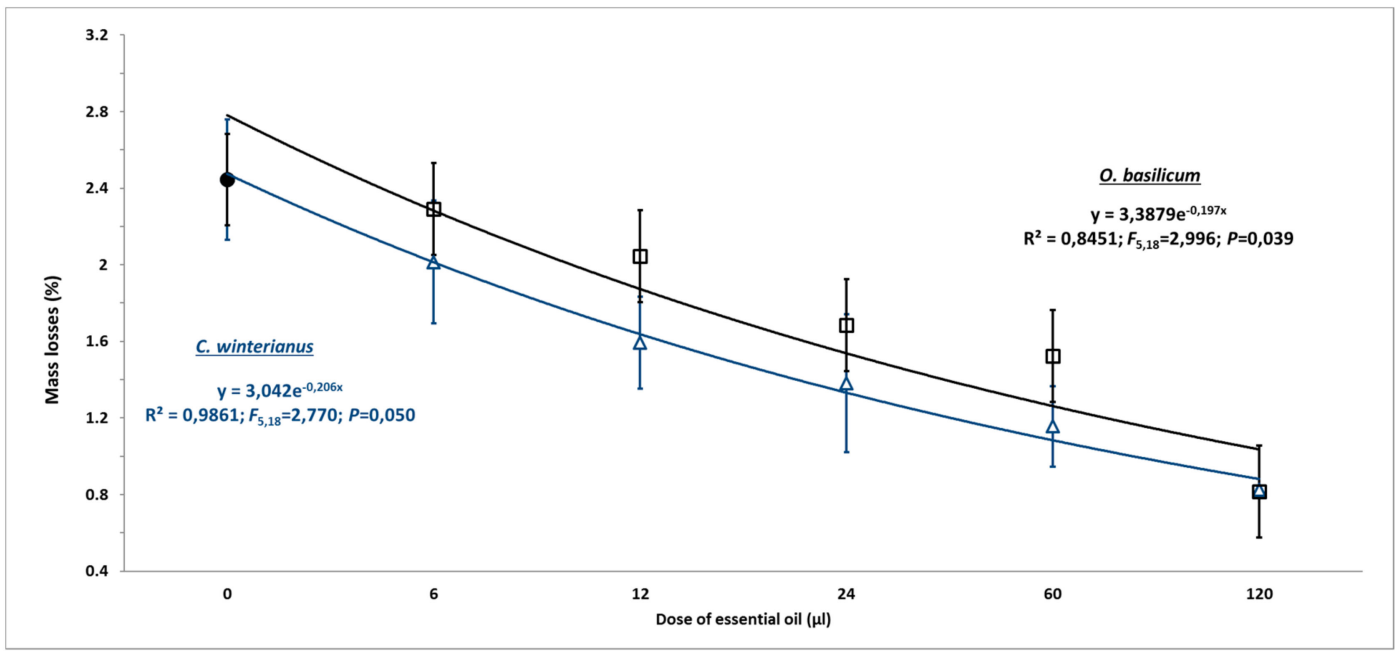

Figure 4. Bean weight losses caused by A. obtectus in $0.33 \mathrm{~L} /$ glass jar on the absence (control) (๑) and the presence of increasing doses of O. basilicum ( $\square$ ) and C. winterianus $(\boldsymbol{\Delta})$ essential oils. The symbols represent the mean of four replicates for each dose of essential oils. Vertical bars represent the Standard Error of the mean (SE).

\section{Discussion}

The essential oils do not constitute a threat to the environment or to human health, and so they have been portrayed as a possible alternative to synthetic insecticides [38]. The essential oils are volatile hydrocarbon mixtures, which have a variety of functional groups [31]. These oils are derived from secondary plant metabolism and play a key role in their development, both directly, through the defense of the plant against microorganisms and herbivores [31]. Many authors [39-41] have described the essential oils to be composed of substances from various chemical groups, such as terpenes (monoterpenes and sesquiterpenes), phenylpropanoids, alcohols, esters, aldehydes, ketones, among others. The biological activity of essential oils depends not only on their chemical composition, but also on the concentration and proportion of these substances [39-41].

The essential oil of O. basilicum was principally composed by the aromatic ether Estragol (74.0\%) and the terpene with alcohol group Linalool (17.8\%), which are known to have repellent and toxic activities against stored product insect [42]. The proportion of main components obtained in O. basilicum oil, were similar to those described by Kim et al. [43] and Souza et al. [35]. The genus Ocimum, belonging to the family Lamiaceae, has been investigated with regard to its insecticidal properties against diverse insect pests $[35,44-46]$.

The main components for $C$. winterianus were the terpenoid mix Citral $(0.7 \%)$, the monoterpenoids Citronellol (11.5\%) and Citronellal (34.0\%), the monoterpenoid with an alcohol Geraniol (22.0\%), and the terpene Limonene (3.5\%), coinciding with those described by Leite et al. [47] and Rodrigues et al. [48]. That is, the main essential oil components of $C$. winterianus oil are the monoterpenes, citronellol, citronellal and geraniol. Monoterpenes possess insecticidal and insect repellent properties, as described by Isman [49], Silva et al. [30] and Chen and Viljoen [50]. The proportion of main components obtained in C. winterianus oil were very similar to those obtained by Renkema et al. [51], Martins et al. [52], and Vieira and Simon [53] described that the chemical composition of essential oils can show large variability, both interspecific and within the same species. It seems to depend on the genetic characteristics of the plant and on the conditions under which it was grown.

These essential oils exhibited similar patterns for insecticidal activity over the A. obtectus when sprayed directly in Petri dishes or indirectly over beans in glass jars using different doses. The insecticidal activity of both oils did not exceed 15 days after application. In the same range, it is well described by Ilboudo et al. [54] for several other essential oils. Losses of activity for essential oils are normally due to degradation of the active compounds. In this respect, essential oils containing more hydrogenated 
compounds are more susceptible to oxidation [55]. Various studies with essential oils obtained from species of the genus Ocimum spp. (O. basilicum and O. gratissimum) showed good results regarding their insecticidal effect against insect pests that attack grains. Kéita et al. [44] evaluated (by fumigation) the effect of O. basilicum and O. gratissimum for the control of Callosobruchus maculatus F. (Coleoptera: Chrysomelidae: Bruchinae) and obtained $80 \%$ and $70 \%$ mortality of the insect population evaluated with $25 \mu \mathrm{L}$. Rozman et al. [42] reported toxicity of fumigated linalool against Tribolium castaneum Herbst (Coleoptera: Tenebrionidae), Rhyzopertha dominica (Coleoptera: Bostrichidae), and Sitophilus oryzae (Coleoptera: Curculionidae), in fumigation with Linalool, one of the main components of basil essential oil, where Linalool was highly effective for R. dominica, and caused $100 \%$ mortality at the lowest tested concentration ( $0.1 \mathrm{~mL} / 720 \mathrm{~mL}$ of volume). Ogendo et al. [46] obtained a $98 \%, 99 \%$, and $100 \%$ mortality against R. dominica, Oryzaephilus surinamensis L. (Coleoptera: Silvanidae) and Callosobruchus chinensis L. (Coleoptera: Chrysomelidae) using $1 \mu \mathrm{L}$ of $O$. gratissimum essential oil per litre of air.

Other studies have shown diverse activities and effects of $C$. winterianus, such as its use an insect repellant [56], its larvicidal effect for certain mosquito species [57], and its insecticidal against Frankliniella schultzei Trybom (Thysanoptera: Thripidae) and Myzus persicae Sulzer (Homoptera: Aphididae) species [58]. Citronella oil caused also repellency on C. maculatus (Fabr) adults [33] and feed deterrence and larval mortality on S. frugiperda Walker (Lepidoptera: Noctuidae) [59].

A. obtectus accumulated emergence decreased with an increase in the doses of both essential oils. This phenomenon can be due to a lower capacity of movement of the insects treated with this dose and/or the oil's direct or indirect effects on the insects (such as repellency and/or anti feeding activity) at one or more of the insect life stages (egg, larva, pupa, and adult), as have been described by Papachristos and Stamopoulos [60] and Schmidt and Streloke [61].

Several authors [62-64] have described different activities of essential oils on eggs and some insect adults. Specifically, for this insect pest, $A$. obtectus, developmental traits, such as adult life span, the ability of larvae to enter the bean, and larva/pupa susceptibilities have been shown to be differentially affected by different essential oils $[18,65]$.

Basil and citronella oils exhibited significant reductions on bean weight and the number of beans damaged by A. obtectus when greater doses were applied over beans. In addition, the high doses (60 and $120 \mu \mathrm{L}$ ) of basil oil generated a greater concentration of holes in the damaged beans, showing the toxic activity of this essential oil through its Linallol component [42]. The behavior and/or repellency shown by A. obtectus towards treated beans has also been observed by Rodríguez-González et al. [66] using biological control agents.

\section{Conclusions}

O. basilicum and C. winterianus essential oils significantly reduced the bean weight losses caused by $A$. obtectus, and significantly reduced the number of beans damaged when doses of 60 or $120 \mu \mathrm{L}$ were applied to them, in addition to concentrating a greater number of holes per bean with the $120 \mu \mathrm{L}$ dose of $O$. basilicum. In addition, these essential oils exhibited similar patterns for insecticidal activities over the insects when these oils were sprayed directly in Petri dishes or indirectly over beans in glass jars. These essential oils affected the development of A. obtectus, since the greatest doses applied on beans decreased the emergence of the bean weevil. The present study supports the insecticidal capacity of basil and citronella essential oils against $A$. obtectus and their potential use in environmentally low risk pest control strategies. Supplementary trials should be conducted under real storage conditions

\section{Reference}

Author Contributions: Á.R.-G. and F.D.S. designed the experiment. S.Á.-G. and Ó.G.-L. conducted the experiments. P.A.C. performed statistical analysis. Á.R.-G., F.D.S., S.Á.-G., Ó.G.-L., and P.A.C. prepared the manuscript. 
Funding: This work was funded by the Ministry of Science, Innovation and Universities (Government of Spain), according to the Resolution of 27 July 2018, (BOE No. 184, of July 31) through the grant awarded to Álvaro Rodríguez González (PTA2017-14403-I).

Acknowledgments: The authors are grateful to the Federal University of Reconcavo de Bahia and especially to Franceli Da Silva for providing us with their knowledge about essential oils.

Conflicts of Interest: The authors declare no conflict of interest.

\section{References}

1. Paul, U.V.; Lossini, J.S.; Edwards, P.J.; Hilbeck, A. Effectiveness of products from four locally grown plants for the management of Acanthoscelides obtectus (Say) and Zabrotes subfasciatus (Boheman) (Coleoptera: Bruchidae) in stored beans under laboratory and farm conditions in Northern Tanzania. J. Stored Prod. Res. 2009, 45, 97-107. [CrossRef]

2. Thakur, D.R. Taxonomy, distribution and pest status of indian biotypes of Acanthoscelides obtectus (Coleoptera: Chrysomelidae: Bruchinae)—A new record. Pak. J. Zool. 2012, 44, 189-195.

3. Vilca Mallqui, K.S.; Oliveira, E.E.; Guedes, R.N.C. Competition between the bean weevils Acanthoscelides obtectus and Zabrotes subfasciatus in common beans. J. Stored Prod. Res. 2013, 55, 32-35.

4. Baier, A.H.; Webster, B.D. Control of Acanthoscelides obtectus Say (Coleoptera: Bruchidae) in Phaseolus vulgaris L. seed stored on small farms-I. Evaluation of damage. J. Stored Prod. Res. 1992, 28, 289-293. [CrossRef]

5. Gołebiowski, M.; Malinski, E.; Nawrot, J.; Stepnowski, P. Identification and characterization of surface lipid components of the dried-bean beetle Acanthoscelides obtectus (Say) (Coleoptera: Bruchidae). J. Stored Prod. Res. 2008, 44, 386-388. [CrossRef]

6. Daglish, G.J.; Hall, E.A.; Zorzetto, M.J.; Lambkin, T.M.; Erbacher, J.M. Evaluation of protectants for control of Acanthoscelides obtectus (Say) (Coleoptera: Bruchidae) in navybeans (Phaseolus vulgaris (L.)). J. Stored Prod. Res. 1993, 29, 215-219. [CrossRef]

7. Kumar, P.; Mishra, S.; Malik, A.; Satya, S. Repellent, larvicidal and pupicidal properties of essential oils and their formulations against the housefly, Musca domestica. Med. Vet. Entomol. 2011, 25, 302-310. [CrossRef]

8. Regnault-Roger, C.; Vincent, C.; Arnason, J.T. Essential oils in insect control: Low-risk products in a high-stakes world. Annu. Rev. Entomol. 2012, 57, 405-424. [CrossRef]

9. Rodríguez-González, Á.; Mayo, S.; González-López, Ó.; Reinoso, B.; Gutierrez, S.; Casquero, P.A. Inhibitory activity of Beauveria bassiana and Trichoderma spp. on the insect pests Xylotrechus arvicola (Coleoptera: Cerambycidae) and Acanthoscelides obtectus (Coleoptera: Chrisomelidae: Bruchinae). Environ. Monit. Assess. 2017, 189, 12. [CrossRef]

10. Castillo, L.; González-Coloma, A.; González, A.; Díaz, M.; Santos, E.; Alonso-Paz, E.; Bassagoda, M.J.; Rossini, C. Screening of Uruguayan plants for deterrent activity against insects. Ind. Crops Prod. 2009, 29, 235-240. [CrossRef]

11. Fang, R.; Jiang, C.H.; Wang, X.Y.; Zhang, H.M.; Liu, Z.L.; Zhou, L.; Du, S.S.; Deng, Z.W. Insecticidal activity of essential oil of Carum carvi fruits from China and its main components against two grain storage insects. Molecules 2010, 15, 9391-9402. [CrossRef]

12. Morais, S.M.; Cavalcanti, E.S.B.; Bertini, L.M.; Oliveira, C.L.L.; Rodrigues, J.R.B.; Cardoso, J.H.L. Larvicidal activity of essential oils from Brazilian croton species against Aedes aegypti L. J. Am. Mosq. Control Assoc. 2006, 22, 161-164. [CrossRef]

13. Murungi, L.K.; Kirwa, H.; Torto, B. Differences in essential oil content of berries and leaves of Solanum sarrachoides (Solanaceae) and the effects on oviposition of the tomato spider mite (Tetranychus evansi). Ind. Crops Prod. 2013, 46, 73-79. [CrossRef]

14. Pavela, R. Insecticidal and repellent activity of selected essential oils against of the pollen beetle, Meligethes aeneus (Fabricius) adults. Ind. Crops Prod. 2011, 34, 888-892. [CrossRef]

15. Campolo, O.; Giunti, G.; Russo, A.; Palmeri, V.; Zappalà, L. Essential Oils in Stored Product Insect Pest Control. J. Food Qual. 2018, 2018, 6906105. [CrossRef]

16. Papachristos, D.P.; Karamanoli, K.I.; Stamopoulos, D.C.; Menkissoglu-Spiroudi, U. The relationship between the chemical composition of three essential oils and their insecticidal activity against Acanthoscelides obtectus (Say). Pest Manag. Sci. 2004, 60, 514-520. [CrossRef] 
17. Regnault-Roger, C.; Hamraoui, A.; Holeman, M.; Theron, E.; Pinel, R. Insecticidal effect of essential oils from mediterranean plants upon Acanthoscelides obtectus Say (Coleoptera: Bruchidae), a pest of kidney bean (Phaseolus vulgaris L.). J. Chem.Ecol. 1993, 19, 1233-1244. [CrossRef]

18. Regnault-Roger, C.; Hamraoui, A. Inhibition of reproduction of Acanthoscelides obtectus Say (Coleoptera), a kidney bean (Phaseolus vulgaris) bruchid, by aro-matic essential oils. Crop Prot. 1994, 13, 624-628. [CrossRef]

19. Weaver, D.K.; Dunkel, F.V.; Ntezurubanza, L.; Jackson, L.L.; Stock, D.T. The efficacy of linalool, a major component of freshly-milled Ocimum canum Sims (Lamiaceae), for protection against postharvest damage by certain stored product Coleoptera. J. Stored Prod. Res. 1991, 27, 213-220. [CrossRef]

20. Enan, E. Insecticidal activity of essential oils: Octopaminergic sites of action. Comp. Biochem. Physiol. C: Toxicol. Pharmacol. 2001, 130, 325-337.

21. Enan, E.E. Molecular and pharmacological analysis of an octopamine receptor from American cockroach and fruit fly in response to plant essential oils. Arch. Insect Biochem. Physiol. 2005, 59, 161-171. [CrossRef]

22. Enan, E.E. Molecular response of Drosophila melanogaster tyramine receptor cascade to plant essential oils. Insect Biochem. Mol. Biol. 2005, 35, 309-321. [CrossRef]

23. Kostyukovsky, M.; Rafaeli, A.; Gileadi, C.; Demchenko, N.; Shaaya, E. Activation of octopaminergic receptors by essential oil constituents isolated from aromatic plants: Possible mode of action against insect pests. Pest Manage. Sci. 2002, 58, 1101-1106. [CrossRef]

24. Bloomquist, J.R.; Boina, D.R.; Chow, E.; Carlier, P.R.; Reina, M.; Gonzalez-Coloma, A. Mode of action of the plant-derived silphinenes on insect and mammalianGABAA receptor/chloride channel complex. Pest. Biochem. Physiol. 2008, 91, 17-23. [CrossRef]

25. Priestley, C.M.; Williamson, E.M.; Wafford, K.A.; Sattelle, D.B. Thymol, a constituent of thyme essential oil, is a positive allosteric modulator of human GABAA receptors and a homo-oligomeric GABA receptor from Drosophila melanogaster. Br. J. Pharmacol. 2003, 140, 1363-1372. [CrossRef]

26. Tong, F.; Coats, J.R. Quantitative structure-activity relationships of monoter-penoid binding activities to the housefly GABA receptor. Pest Manage. Sci. 2012, 68, 1122-1129. [CrossRef]

27. Keane, S.; Ryan, M.F. Purification, characterisation, and inhibition by monoterpenes of acetylcholinesterase from the waxmoth, Galleria mellonella (L.). Insect Biochem. Mol. Biol. 1999, 29, 1097-1104. [CrossRef]

28. López, M.D.; Pascual-Villalobos, M.J. Mode of inhibition of acetyl-cholinesterase by monoterpenoids and implications for pest control. Ind. Crops Prod. 2010, 31, 284-288. [CrossRef]

29. Ryan, M.; Byrne, O. Plant-insect coevolution and inhibition of acetylcholine-esterase. J. Chem. Ecol. 1988, 14, 1965-1975. [CrossRef]

30. Silva, C.T.S.; Wanderley-Teixeira, V.; Cunha, F.M.; Oliveira, J.V.; Dutra, K.A.; Ferraz-Navarro, D.M.A.; Teixeira, A.A.C. Effects of citronella oil (Cymbopogon winterianus Jowitt ex Bor) on Spodoptera frugiperda (J.E. Smith) midgut and fat body. Biotech. Histochem. 2017, 93, 1-13. [CrossRef]

31. Cruz, G.; Wanderley-Teixeira, V.; Marques da Silva, L.; Andrade Dutra, K.; Arruda Guedes, C.; Vargas de Oliveira, J.; Ferraz Navarro, D.M.A.; Caldas Araújo, B.; Aguiar, A.; Teixeira, C. Chemical composition and insecticidal activity of the essential oils of Foeniculum vulgare Mill., Ocimum basilicum L., Eucalyptus staigeriana F. Muell. ex Bailey, Eucalyptus citriodora Hook and Ocimum gratissimum L. and their major components on Spodoptera frugiperda (Lepidoptera: Noctuidae). J. Essent Oil Bear Pl. 2017, 20, 1360-1369.

32. Deletre, E.; Chandre, F.; Williams, L.; Duménil, C.; Menut, C.; Martin, T. Electrophysiological and behavioral characterization of bioactive compounds of the Thymus vulgaris, Cymbopogon winterianus, Cuminum cyminum and Cinnamomum zeylanicum essential oils against Anopheles gambiae and prospects for their use as bednet treatments. Parasites Vectors 2015, 8, 316. [CrossRef] [PubMed]

33. Gusmão, N.M.S.; de Oliveira, J.V.; Navarro, D.M.d.A.F.; Dutra, K.A.; da Silva, W.A.; Wanderley, M.J.A. Contact and fumigant toxicity and repellency of Eucalyptus citriodora Hook., Eucalyptus staigeriana F., Cymbopogon winterianus Jowitt and Foeniculum vulgare Mill. essential oils in the management of Callosobruchus maculatus (FABR.) (Coleoptera: Chrysomelidae, Bruchinae). J. Stored Prod. Res. 2013, 54, 41-47.

34. Islam, T.; Iqbal, J.; Abdullah, K.; Khan, E.A. Evaluation of some plant extracts against maize weevil, Sitophilus zeamais (Coleoptera: Curculionidae) under laboratory conditions. Pak. J. Agr. Sci. 2017, 54, 737-741.

35. Souza, V.N.; de Oliveira, C.R.F.; Cysneiros Matos, C.H.; de Almeida, D.K.F. Fumigation toxicity of essential oils against Rhyzopertha dominica (F.) in stored maize grain. Revista Caatinga 2016, 29, 435-440. [CrossRef]

36. Potter, C. An Improved laboratory apparatus for applying direct sprays and surface films, with data on the electrostatic charge on atomized spray fluids. Ann. Appl. Biol. 1952, 39, 1-28. [CrossRef] 
37. Abbott, W. A method of computing the effectiveness of an insecticide. J. Econ. Entomol. 1925, 18, $265-267$. [CrossRef]

38. Viteri-Jumbo, L.O.; Faroni, L.R.A.; Oliveiraa, E.E.; Pimentel, M.A.; Silva, G.N. Potential use of clove and cinnamon essential oils to control the bean weevil, Acanthoscelides obtectus Say, in small storage units. Ind. Crops Prod. 2014, 56, 27-34. [CrossRef]

39. Siani, C.A.; Sampaio, A.L.F.; Sousa, M.C.; Henriques, M.G.M.O.; Ramos, M.F.S. Óleos essenciais: Potenciais inflamatórios. Biotecnolog. Cienc. Desenvolv. 2000, 16, 38-43.

40. Silveira, M.S. Chemical composition and antibacterial activity of essential oils from Cymbopogon winterianus (citronella), Eucalyptus paniculata (eucalyptus) and Lavandula angustifolia (lavender). Rev. Inst. Adolfo. Lutz. 2012, 71, 471-480.

41. Ringuelet, J.A.; Ocampo, R.; Henning, C.; Padín, S.; Urritia, M.I.; Bello, D. Actividad insecticida del aceite esencial de Lippia alba (Mill.) N.E. Brown sobre Tribolium castaneum Herbst. en granos de trigo (Triticum aestivum L.). Rev. Bras. Agroecol. 2014, 9, 214-222.

42. Rozman, V.; Kalinovic, I.; Korunic, Z. Toxicity of naturally occurring compounds of Lamiaceae and Lauraceae to three stored products insects. J. Stored Prod. Res. 2007, 43, 349-355. [CrossRef]

43. Kim, K.H.; Yi, C.G.; Ahn, Y.J.; Kim, S.I.; Leea, S.G.; Kima, J.R. Fumigant toxicity of basil oil compounds and related compounds to Thrips palmi and Orius strigicollis. Pest Manag. Sci. 2015, 1292-1296. [CrossRef]

44. Kéita, S.M.; Vincent, C.; Schmit, J.P.; Arnason, J.T.; Bélanger, A. Efficacy of essential oil of Ocimum basilicum L. and O. gratissimum L. applied as an insecticidal fumigant and powder to control Callosobruchus maculatus (Fab.) (Coleoptera: Bruchidae). J. Stored Prod. Res. 2001, 37, 339-349. [CrossRef]

45. Lopez, M.D.; Jordan, M.J.; Pascual-Villalobos, M.J. Toxic compounds in essential oils of coriander, caraway and basil active against stored rice pests. J. Stored Prod. Res. 2008, 44, 273-278. [CrossRef]

46. Ogendo, J.O.; Kostyukovsky, M.; Ravid, U.; Matasyoh, J.C.; Deng, A.L.; Omolo, E.O.; Kariuki, S.T.; Shaaya, E. Bioactivity of Ocimum gratissimum L. oil and two of its constituents against five insect pests attacking stored food products. J. Stored Prod. Res. 2008, 44, 328-334. [CrossRef]

47. Leite, B.L.S.; Souza, T.T.; Antoniolli, A.R.; Guimarãee, A.G.; Siqueira, R.S.; Quintans, J.S.S.; Bonjardim, L.R.; Alves, P.B.; Blank, A.F.; Botelho, M.A.; et al. Volatile constituents and behavioral changes induced by Cymbopogon winterianus leaf essential oil in rodents. Afr. J. Biotechnol. 2011, 10, 8312-8319.

48. Rodrigues, K.A.F.; Dias, C.N.; Amaral, F.M.M.; Moraes, D.F.C.; Mouchrek Filho, V.E.; Andrade, E.H.A.; Maia, J.G.S. Molluscicidal and larvicidal activities and essential oil composition of Cymbopogon winterianus. Pharm. Biol. 2013, 51, 1293-1297. [CrossRef]

49. Isman, M.B. Botanical insecticides, deterrents, and repellents in modern agriculture and an increasingly regulated world. Ann. Rev. Entomol. 2006, 51, 45-66. [CrossRef]

50. Chen, W.; Viljoen, A.M. Geraniol-a review of a commercially important fragrance material. S. Afr. J. Bot. 2010, 76, 643-651. [CrossRef]

51. Renkema, J.M.; Buitenhuis, R.; Hallett, R.H. Reduced Drosophila suzukii infestation in berries using deterrent compounds and laminate polymer flakes. Insects 2017, 8, 117. [CrossRef]

52. Martins, A.P.; Salgueiro, L.R.; Vila, R.; Tomi, F.; Canigueral, S.; Casanova, J.; da Cunha, A.P.; Adzet, T. Composition of the essential oils of O. canum, O. gratissimum and O. minimum. Planta Med. 1999, 65, 187-189. [CrossRef]

53. Viera, R.F.; Simon, J.E. Chemical characterization of basil (Ocimum spp.) found in the markets and used in the traditional medicine in Brazil. Econ. Bot. 2000, 54, 207-216. [CrossRef]

54. Ilboudo, Z.; Dabiré, L.C.B.; Nébié, R.C.H.; Dicko, I.O.; Dugravot, S.; Cortesero, A.M.; Sanon, A. Biological activity and persistence of four essential oils towards the main pest of stored cowpeas, Callosobruchus maculatus (F.) (Coleoptera: Bruchidae). J. Stored Prod. Res. 2010, 46, 124-128. [CrossRef]

55. Kim, S.-I.; Roh, J.-Y.; Kim, D.-H.; Lee, H.-S.; Ahn, Y.-J. Insecticidal activities of aromatic plant extracts and essential oils against Sitophilus oryzae and Callosobruchus chinensis. J. Stored Prod. Res. 2003, 39, $293-303$. [CrossRef]

56. Martins, R.M. Estudio in vitro de la acción acaricida del aceite esencial de la gramínea citronela de Java (Cymbopogon winterianus Jowitt) en la garrapata Boophilus microplus. Rev. Bras. Pl. Med. 2006, 8, 71-78.

57. Furtado, R.F.; Lima, M.G.A.; Andrade-Neto, M.; Bezerra, J.N.S.; Silva, M.G.V. Atividade larvicida de óleos essenciais contra Aedes aegypti L. (Diptera: Culicidae). Neotrop. Entomol. 2005, 34, 843-847. [CrossRef] 
58. Pinheiro, P.F.; Queiroz, V.T.; Rondelli, V.M.; Costa, A.V.; Marcelino, T.; Pratissoli, D. Insecticidal activity of citronella grass essential oil on Frankliniella schultzei and Myzus persicae. Ciên. Agrotec. 2013, 37, 138-144. [CrossRef]

59. Labinas, M.A.; Crocomo, W.B. Effect of java grass (Cymbopogon winteranus) essential oil on fall armyworm Spodoptera frugiperda (J.E. Smith, 1979) (Lepidoptera, Noctuidae). Acta Sci. 2002, 24, 1401-1405.

60. Papachristos, D.P.; Stamopoulos, D.C. Repellent, toxic and reproduction inhibitory effects of essential oil vapours on Acanthoscelides obtectus (Say) (Coleoptera: Bruchidae). J. Stored Prod. Res. 2002, 38, 117-128. [CrossRef]

61. Schmidt, G.H.; Streloke, M. Effect of Acorus calamus (L.) (Araceae) oil and its main compound $\beta$-asarone on Prostephanus truncatus (Horn) (Coleoptera: Bostrichidae). J. Stored Prod. Res. 1994, 30, 227-235. [CrossRef]

62. Abd El-Salama, A.M.E. Toxic and deterrent effects of two volatile oils against cowpea weevil, Callosobruchus chinensis (Coleoptera: Bruchidae). Arch. Phytopathol. Plant Prot. 2013, 43, 1596-1607. [CrossRef]

63. Yang, Y.-C.; Lee, S.-H.; Lee, W.-J.; Choi, D.-H.; Ahn, Y.-J. Ovicidal and adulticidal effects of Eugenia caryophyllata bud and leaf oil compounds on Pediculus capitis. J. Agric. Food Chem. 2003, 51, 4884-4888. [CrossRef]

64. Yang, Y.-C.; Lee, H.-S.; Lee, S.H.; Clark, J.M.; Ahn, Y.-J. Ovicidal and adulticidal activities of Cinnamomum zeylanicum bark essential oil compounds and related compounds against Pediculus humanus capitis (Anoplura: Pediculicidae). Int. J.Parasitol. 2005, 35, 1595-1600. [CrossRef]

65. Papachristos, D.P.; Stamopoulos, D.C. Toxicity of vapours of three essential oils to the immature stages of Acanthoscelides obtectus (Say) (Coleoptera: Bruchidae). J. Stored Prod. Res. 2002, 38, 365-373. [CrossRef]

66. Rodríguez-González, Á.; Casquero, P.A.; Suárez-Villanueva, V.; Carro-Huerga, G.; Álvarez-García, S.; Mayo-Prieto, S.; Lorenzana, A.; Cardoza, R.E.; Gutiérrez, S. Effect of trichodiene production by Trichoderma harzianum on Acanthoscelides obtectus. J. Stored Prod. Res. 2018, 77, 231-239. [CrossRef]

(C) 2019 by the authors. Licensee MDPI, Basel, Switzerland. This article is an open access article distributed under the terms and conditions of the Creative Commons Attribution (CC BY) license (http://creativecommons.org/licenses/by/4.0/). 